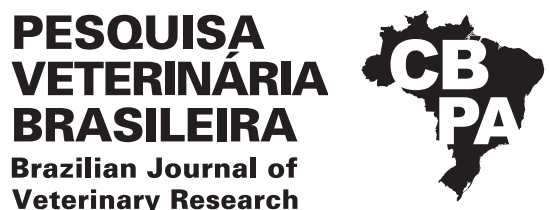

Pesq. Vet. Bras. 40(6):438-442, June 2020 DOI: 10.1590/1678-5150-PVB-6535

Original Article

Veterinary Research

ISSN 0100-736X (Print)

ISSN 1678-5150 (Online)

\title{
Spontaneous poisoning by Stryphnodendron rotundifolium var. villosum in cattle ${ }^{1}$
}

\author{
Igor R. Santos ${ }^{2}$ (D) Janaína C. Lima², Fábio H. Oliveira3 ${ }^{3}$ Hugo H. Ferreira ${ }^{4}$, \\ Marcus V.V. Ramos ${ }^{5}$ and Adriana S. Santos ${ }^{2 *}$ (D)
}

\begin{abstract}
Santos I.R., Lima J.C., Oliveira F.H., Ferreira H.H., Ramos M.V.V. \& Santos A.S. 2020. Spontaneous poisoning by Stryphnodendron rotundifolium var. villosum in cattle. Pesquisa Veterinária Brasileira 40(6):438-442. Laboratório de Histologia e Patologia Animal, Instituto Federal Goiano Campus Urutaí, Rodovia Geraldo Silva Nascimento Km 2,5, Zona Rural, Urutaí, GO 75790-000, Brazil. E-mail: adriana.santos@ifgoiano.edu.br

This is a report on an outbreak of cattle poisoning by Stryphnodendron rotundifolium var. villosum (Benth.) Scalon in the state of Goiás in Brazil. In a herd of 80 cattle that consumed the mature fruit of this plant that was present in their pasture, 12 animals fell ill and died. The clinical signs that they presented were apathy, progressive weight loss, reeling, bristling, and dry stools containing seeds. The main necropsy findings were jaundice, an increased lobular pattern and orange coloration in their liver, enlarged kidneys with yellowish medullae, and pre-stomachs containing fruit peels and seeds. A histopathological examination revealed vacuolar degeneration and necrosis in the liver and kidneys and vacuolar degeneration in the rumen, omasum, reticulum, and intestine. The diagnosis of poisoning by $S$. rotundifolium var. villosum was based on epidemiological data, clinical findings, and pathological changes. Our results can aid in the differentiation between poisoning by S. rotundifolium var. villosum and poisoning by other toxic plants that are of interest to lifestock.
\end{abstract}

INDEX TERMS: Spontaneous poisoning, Stryphnodendron rotundifolium, cattle, barbatimão, cattle poisoning, Goiás, poisonous plants.

RESUMO.- [Intoxicação espontânea por Stryphnodendron rotundifolium var. villosum em bovinos.] Relata-se um surto de intoxicação em bovinos por Stryphnodendron rotundifolium var. villosum (Benth.) Scalon no estado de Goiás, Brasil. De um rebanho composto por 80 bovinos, os quais consumiram frutos maduros da planta presente na pastagem, 12 animais adoeceram e morreram. Os sinais clínicos apresentados foram apatia, emagrecimento progressivo, andar cambaleante, pelo eriçado e fezes secas contendo sementes. Os principais achados de necropsia foram icterícia, fígado com padrão lobular e coloração alaranjada, rins aumentados e com amarelamento da medular e pré-estômagos com presença

\footnotetext{
${ }^{1}$ Received on February 18, 2020.

Accepted for publication on March 4, 2020.

${ }^{2}$ Laboratório de Histologia e Patologia Animal, Instituto Federal Goiano Campus Urutaí, Rodovia Geraldo Silva Nascimento Km 2,5, Zona Rural, Urutaí, G0 75790-000, Brazil. *Corresponding author: adriana.santos@ifgoiano.edu.br

${ }^{3}$ Agência Goiana de Defesa Agropecuária, Rua Marechal Floriano Peixoto 39, Centro, Ipameri, GO 75780-000, Brazil.

${ }^{4}$ Médico Veterinário, Rua 54 142, Jardim Goiás, Goiânia, G0 74810-220, Brazil.

${ }^{5}$ Herbário, Instituto Federal Goiano, Campus Urutaí, Rodovia Geraldo Silva Nascimento Km 2,5, Zona Rural, Urutaí, GO 75790-000, Brazil.
}

de cascas e sementes do fruto. Ao exame histopatológico, notou-se degeneração vacuolar e necrose no fígado e rins e degeneração vacuolar no rúmen, omaso, retículo e intestino. 0 diagnóstico da intoxicação por $S$. rotundifolium var. villosum baseou-se nos dados epidemiológicos, nos achados clínicos e nas alterações patológicas. Nossos resultados podem auxiliar na diferenciação entre a intoxicação por $S$. rotundifolium var. villosum e a intoxicação por outras plantas tóxicas de interesse pecuário.

TERMOS DE INDEXAÇ̃̃O: Intoxicação espontânea, Stryphnodendron rotundifolium, bovinos, barbatimão, Goiás, intoxicação em bovinos, planta tóxica.

\section{INTRODUCTION}

Stryphnodendron rotundifolium Mart., popularly known as "barbatimão", belongs to the Fabaceae family (=Leguminosae) and Mimosoideae subfamily. The species has two varieties: $S$. rotundifolium Mart. var. rotundifolium (syn. S. obovatum Benth., S. discolor Benth., and S. rotundifolium f. retusa Chodat \& Hassl) and $S$. rotundifolium var. villosum (Benth.) Scalon (syn. Stryphnodendron goyazence Taub. and Stryphnodendron 
humile E.M.O. Martins). The S. rotundifolium var. rotundifolium is found in the Midwestern, Southeastern, Northeastern, and Northern regions of Brazil and is described as being toxic for cattle (Camargo 1965, Tokarnia et al. 1998, Brito et al. 2001a, 2001b, Braga et al. 2018).

Despite the fact that veterinarians and farmers have cited that $S$. rotundifolium var. villosum is also toxic to cattle, so far, there have been few reports regarding poisoning due to the consumption of this plant. This variety is shrubby to arboreal, reaches up to $6 \mathrm{~m}$ in height, and is widely distributed in the central Brazilian "cerrado" (savanna type vegetation) that is found in the Federal District, states of Goiás, Mato Grosso, and Mato Grosso do Sul (Scalon 2007).

In this study, we aimed to describe the epidemiological, clinical, and pathological characteristics associated with an outbreak of spontaneous poisoning by $S$. rotundifolium var. villosum in cattle.

\section{MATERIALS AND METHODS}

An outbreak of plant poisoning in cattle was investigated. Epidemiological and clinical data were obtained from a veterinarian and the cattle owner during visits to the property. Fragments of various organs were collected from the necropsied animals, following which they were fixed in 10\% formaldehyde, routinely processed for histopathology, and stained with hematoxylin eosin (HE).

Samples of plants suspected of being the cause for the poisoning were collected, and the species were identified by examining their morphological characteristics and distribution areas and by consulting the herbarium of the "Instituto Federal Goiano", Campus Urutaí, where the exsiccate of Stryphnodendron rotundifolium var. villosum (Benth.) Scalon was registered under the number 758. Pluvial precipitation values that were evaluated during the intoxication period were obtained from the Instituto Nacional de Meteorologia (INMET 2018).

\section{RESULTS}

\section{Plant identification}

The plants were arboreal in size, measuring approximately 3-5m in height (Fig.1A). The leaves were bipinnate with a pubescent rachis and petiole measuring $12-21 \mathrm{~cm}$ in length. The pinnae consisted of 9-11 pairs organized in an alternate or opposite arrangement, measuring 3-9cm in length. Each pinna contained 10-13 pairs of follicles that had a slightly asymmetric base and that were arranged alternate to or opposite each other with sessile or short petioles that were discolored, villous, and measured 8-14mm in length.

The inflorescences were arranged in axillary spikes that were $2-7 \mathrm{~cm}$ long and were on a peduncle that was $2-3 \mathrm{~cm}$ long. The fruit were indehiscent, erect or slightly curved, $9-10 \mathrm{~cm}$ long, reddish brown, puberulous, and brilliant. Each fruit had 10-12 smooth, ellipsoid-shaped seeds that were 7-8mm long with a dark brown forehead and a yellowish-brown pleurogram. The species was identified as Stryphnodendron rotundifolium var. villosum (Benth.) Scalon (Fig.1B).

\section{Epidemiological and clinical findings}

The outbreak occurred on a property located in the municipality of Ipameri (latitude $17^{\circ} 71^{\prime} \mathrm{S}$, longitude $48^{\circ} 16^{\prime}$ W, and altitude $772.99 \mathrm{~m}$ ) in Southeastern Goiás during the second week of September 2018. The total rainfall in this region from August to September 2018 was $71.0 \mathrm{~mm}$.

The studied herd consisted of 80 Nelore cattle that were reared via an extensive system ( 9 between $0-12$ months, 11 between 13-24 months, 15 between 25-36 months, and 45 over 36 months). The animals were confined to an enclosure of approximately 19 hectares in size covered with Brachiaria brizantha (Hochst. ex A. Rich.) Stapf [syn. Urochloa brizantha (Hochst. ex A. Rich.) R. D. Webster] and native "cerrado" vegetation among which were numerous individual $S$. rotundifolium var. villosum plants with ripe fruits. Further, concerning other toxic plants that may interest livestock, only Palicourea marcgravii St. Hil. was identified on the property. The animals were only supplemented with mineral protein.
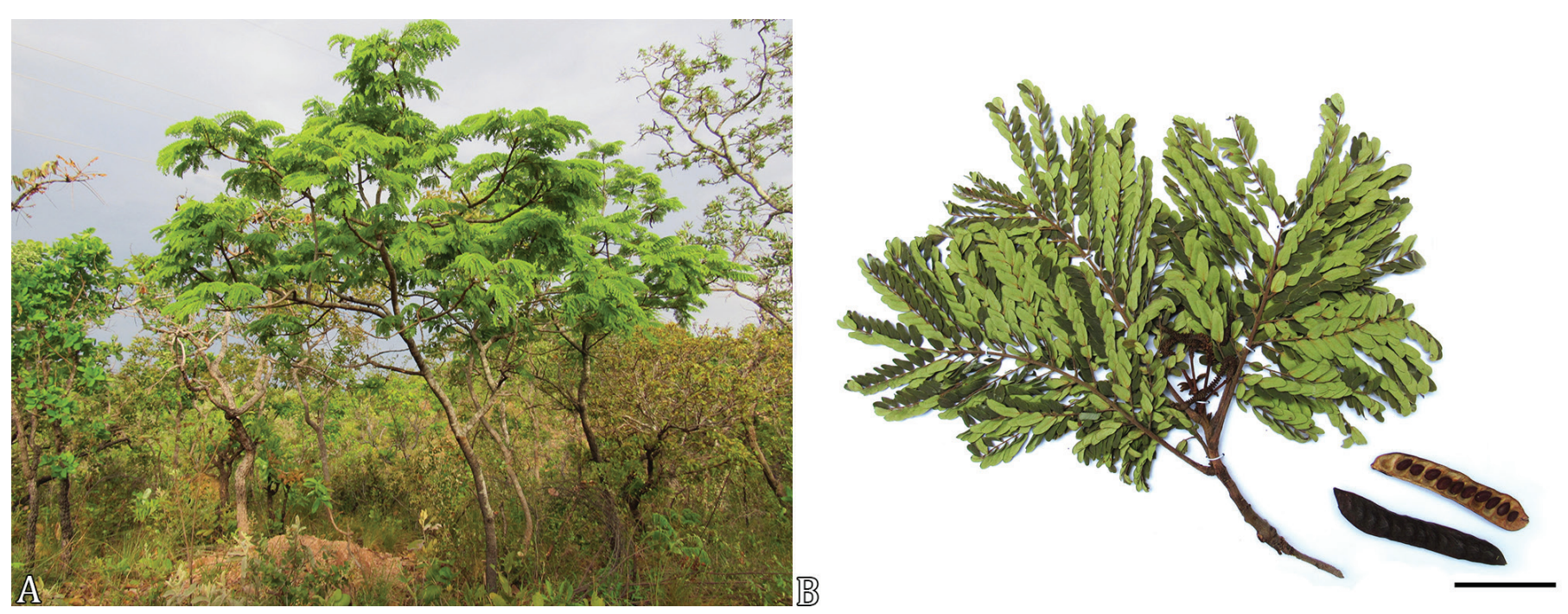

Fig.1. (A) Native "Cerrado" area containing specimens of Stryphnodendron rotundifolium var. villosum, Ipameri, Goiás, October 2018. (B) The exsiccata including vegetative and reproductive samples from Stryphnodendron rotundifolium var. villosum. Bar $=5 \mathrm{~cm}$. 
Twelve animals ( 4 between 13-24 months and 8 over 36 months) exhibited signs of poisoning and died (morbidity and mortality $9.6 \%$ and lethality $100 \%$ ). The first clinical sign observed was apathy, followed by progressive weight loss (Fig.2), reeling, bristling, and dry stools containing seeds of $S$. rotundifolium var. villosum. The period between the onset of first clinical signs and the animals' death ranged from 10 to 15 days. The affected herd was supplemented with hay and was removed from the pasture after the first deaths.

\section{Necropsy and histopathological findings}

Two bovines were necropsied and were found to have similar macroscopic lesions. Dehydration, cachexia, and pale oral and ocular mucosa were observed. The bovines' prestomachs contained a moderate number of seeds and peels of the fruit of $S$. rotundifolium var. villosum (Fig.3). In the liver, an evident lobular pattern and orange coloration were noted
(Fig.4A). The gallbladder was distended and thick-walled, and the kidneys were enlarged with yellowish marked medullae. Our other findings included mild to moderate yellowing of the subcutaneous tissues, tracheal mucosa, abdominal free fluid, and cerebrospinal fluid.

Histologically, there was marked diffuse hepatocellular vacuolization in the liver (Fig.4B), marked centrilobular necrosis, mild and multifocal retention of bile pigment in the bile ducts. An aggregate of random foamy macrophages was observed with negative structures, like crystals, in their cytoplasms. In the kidneys, tubular epithelium exhibited mild multifocal vacuolar degeneration and rare moderate individual necrosis. Multifocally, the mucosal epithelium of the rumen, reticulum, omasum, and intestine exhibited mild vacuolar degeneration. In the mesenteric lymph nodes, we observed multifocal hemosiderosis.

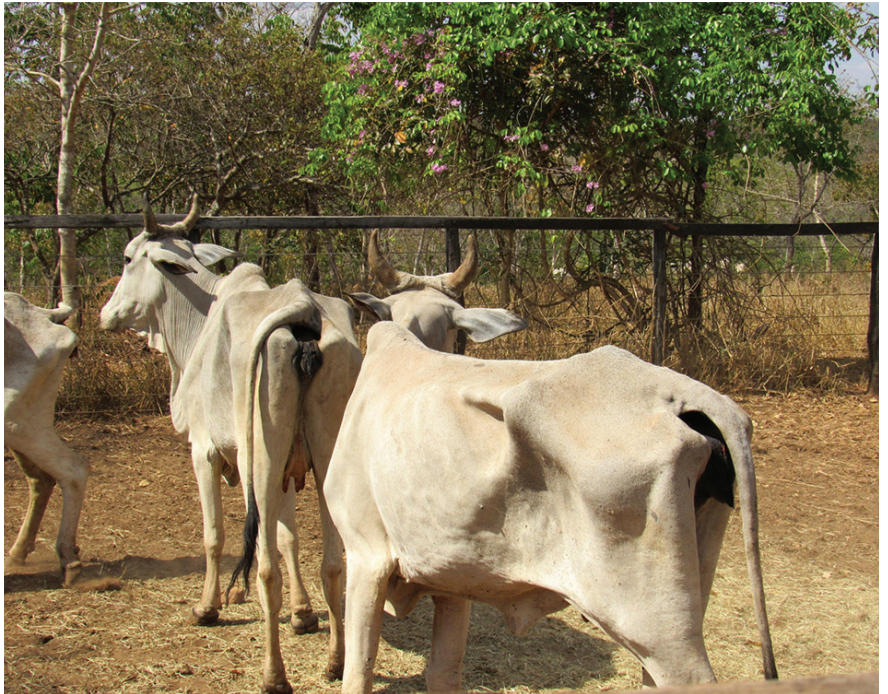

Fig.2. Cattle exhibiting cachexia. Spontaneous poisoning by Stryphnodendron rotundifolium var. villosum in cattle.

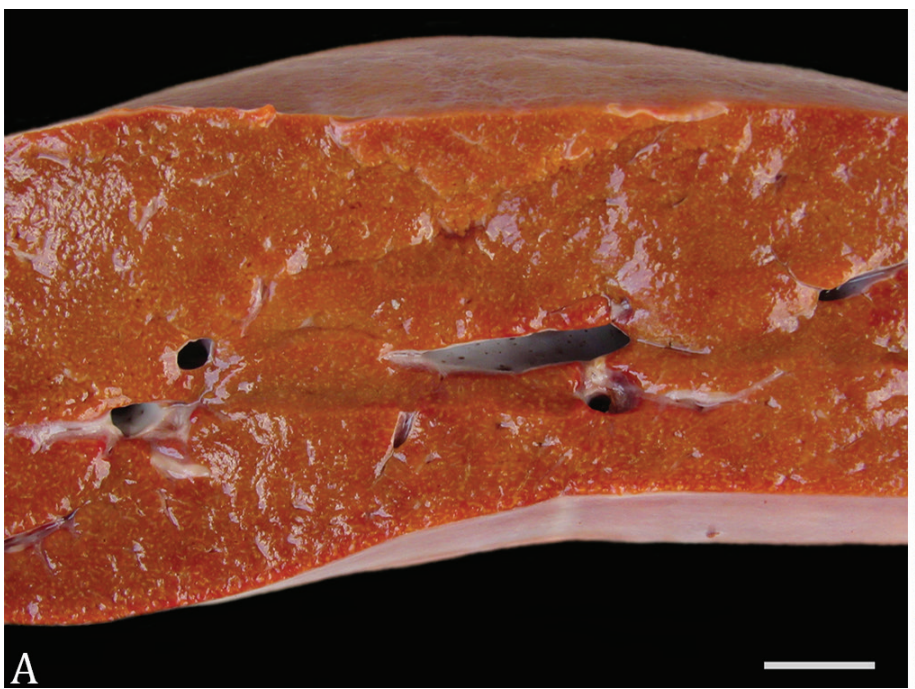

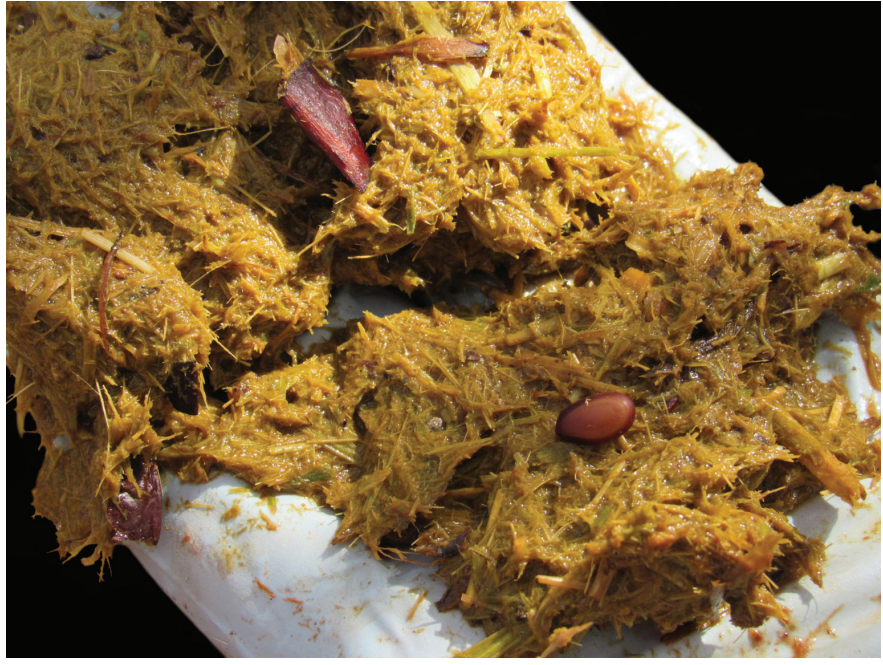

Fig.3. Ruminal content of the cattle containing peels and seeds of the fruit of Stryphnodendron rotundifolium var. villosum. Spontaneous poisoning by Stryphnodendron rotundifolium var. villosum in cattle.

Fig.4. (A) Liver with a cut surface exhibiting orange coloration and evidence of a lobular pattern. Bar = $1 \mathrm{~cm}$. Spontaneous poisoning by Stryphnodendron rotundifolium var. villosum in cattle. (B) Hepatocytes with abundant, pale, and finely vacuolated cytoplasms. Degeneration, liver, spontaneous poisoning by Stryphnodendron rotundifolium var. villosum in cattle. $\mathrm{HE}, \mathrm{bar}=100 \mu \mathrm{m}$. 


\section{DISCUSSION}

The indications suggesting fruit intake by the cattle, epidemiological data, clinical findings, and pathological changes led to the diagnosis of poisoning by Stryphnodendron rotundifolium var. villosum (Benth.) Scalon.

Due to overlapping locations and morphological similarities among some species or among varieties of a single species of the genus Stryphnodendron, it can be difficult for field veterinarians to identify them. In these situations that are similar to those described in this study, it is recommended to send plant samples containing vegetative and reproductive structures for botanical analysis. In the specific case of the two varieties of $S$. rotundifolium Mart., the main morphological difference that can be observed to differentiate them is the presence of trichomes on the branches, petioles, rachis, second order petioles, rachioles, and folioles in S. rotundifolium var. villosum (Scalon 2007).

The farm where the outbreak occurred was already used for extensive cattle rearing in previous years; however, poisoning was never previously observed at the site. The extreme drought that occurred in the region may have caused forage shortages. It has been suggested that the drought situation that is associated with a high density in the population of $S$. rotundifolium var. villosum plants with ripe fruits may have caused the occurrence of intoxication. This type of situation has already been described in other studies on spontaneous poisoning by the Stryphnodendron spp. (Brito et al. 2001a, Ferreira et al. 2009).

In this study, spontaneous $S$. rotundifolium var. villosum poisoning in the affected cattle resulted in mild and nonspecific clinical signs that were characterized by apathy, progressive weight loss, reeling, bristling, and dry stools. The clinical picture described in previous studies that characterized the poisoning by S. rotundifolium Mart. var. rotundifolium, another variety of the same species, was not evidenced in this report; poisoning by this variety is mainly associated with digestive tract lesions (Brito et al. 2001a, Braga et al. 2018), abortions (Tokarnia et al. 1998), and severe lesions compatible with photosensitization (Camargo 1965).

Among all the necropsy findings, only jaundice (Camargo (1965) and an enlarged liver with yellowish coloration (Braga et al. 2018) were noted in the case of poisoning by $S$. rotundifolium var. rotundifolium. Gross lesions in the pre-stomach (papilla redness and adherence, mucosal detachment, congestion, gas tympanic fluid, and foul-smelling ruminal fluid), abomasum (congestion, erosions, and ulcerations), and intestines (congestion and Peyer's plaques evidenced) that were observed in experimentally poisoned cattle (Brito et al. 2001b, Braga et al. 2018) were also not evidenced in this study.

Marked histopathological findings that were observed in the liver of the examined cattle may potentially be related to jaundice owing to reduced bilirubin metabolism and bile duct obstruction (Werner 2011). Vacuolar degeneration and necrosis of the liver associated with photosensitization and jaundice have been described in cases of poisoning by $S$. rotundifolium var. rotundifolium (Camargo 1965). These histopathological findings were recently outlined by Braga et al. (2018) in an experimental study; however, their cases presented mild intensity and absence of photosensitization and jaundice. It is suggested that clinical signs variations may occur in animals due to differences in the clinical course of intoxication and extent of sun exposure.

The severe histopathological findings compatible with ruminal acidosis described in cattle experimentally poisoned by $S$. rotundifolium var. rotundifolium were not observed in this study. Acanthosis, spongiosis, parakeratosis, hyperkeratosis, necrosis, and hydropic-vacuolar degeneration have been reported (Brito et al. 2001b) to be present through the oral cavity to the omasum. The lesions in the intestine result in necrotizing enteritis (Braga et al. 2018), congestion, and bleeding (Brito et al. 2001b). These differences are potentially a result of the course of poisoning.

Due to the occasional presence of foamy macrophage aggregates in the liver, poisoning by Brachiaria spp. was considered as a differential diagnosis. However, this histopathological change can be observed in cases involving the chronic ingestion of this plant by cattle (Driemeier et al.1998) and does not necessarily indicate intoxication (Araújo et al. 2017). Most cases of Brachiaria spp. poisoning occur in cattle with photosensitization and rarely occur in animals over two years of age (Souza et al. 2010); further, the clinical and epidemiological features differ from those observed in this study.

Among the toxic plants that grow in the Brazilian CentralWest region and that can cause liver, kidney, and digestive tract lesions in cattle (Lemos \& Lima 2017), it is necessary to consider poisoning by S. fissuratum E.M.O Martins as a differential diagnosis. The clinical-pathological condition observed in cattle poisoned by $S$. fissuratum (Ferreira et al. 2009) is partially similar to that observed in this study; however, it presents with severely intense findings that are compatible with those of renal and hepatic insufficiency and photosensitization cases (Lazaro et al. 2018). In addition to these differences, this plant was not identified in the region where the outbreak occurred.

So far, it is not clear which toxic principles are responsible for the clinical-pathological picture found in cattle poisoned by the $S$. rotundifolium. A recent experimental study on mice has revealed the hepatotoxicity of the ethanolic extract extracted from the bark of $S$. rotundifolium (unspecified variety) (Aquino et al. 2017). This extract contains numerous secondary metabolites including tannins, flavonoids, and alkaloids (Oliveira 2010). In addition, saponins have been cited as being potentially responsible for the poisoning due to S. rotundifolium var. rotundifolium (Brito et al. 2001a). However, there was no evidence to support that ethanolic extract and saponins were responsible for the lesions found in the cattle in this report.

The main prophylaxis measures that can be implemented to prevent cattle poisoning by the Stryphnodendron spp. include not leaving the animals in areas containing the plant in the dry season or eliminating all their grazing specimens (Tokarnia et al. 2012). As there is no evidence that the fruits of $S$. rotundifolium var. villosum are palatable to cattle, unlike in the case of S. fissuratum (Ferreira et al. 2009) and $S$. rotundifolium var. rotundifolium poisoning (Brito et al. 2001a), it is suggested that supplementation with roughage in the dry period may also be effective. This measure could prevent animals from seeking fruits in the months of low forage availability. 


\section{CONCLUSIONS}

The drought situation that is associated with the presence of Stryphnodendron rotundifolium var. villosum with ripe fruits was a determining factor responsible for the poisoning.

Additionally, our results can aid in the differentiation between poisoning by $S$. rotundifolium var. villosum and poisoning by other toxic plants that are of interest to livestock.

Acknowledgements.- This research was partially supported by "Instituto Federal Goiano" scientific initiation scholarship program.

Conflict of interest statement.- The authors have no competing interests.

\section{REFERENCES}

Aquino M.D.A., Teles A.A.B., Holanda V.N., Menezes I.R.A. \& Vandesmet V.C.S. 2017. Avaliação da atividade hepática do extrato hidroalcóolico da casca Stryphnodendron rotundifolium Mart. Revta Interfaces 5(15):48-54. <http://dx.doi.org/10.16891/2317-434X.v5.e15.a2017pp48-54>

Araújo R.R., Pupin R.C., Madureira R.C., Morais L.G., Quevedo L.S, Lemos R.A.A., Schild A.L., Colodel E.M. \& Castro M.B. 2017. Caracterização e frequência das alterações histológicas nos fígados de bovinos mantidos em pastagens de Brachiaria spp. provenientes de abatedouros no Brasil. Acta Scient. Vet. 45:1432.

Braga L.G., Lima V.H., Rodrigues M.K.F., Silva N.A.A., Cordeiro J.S., Jácome R.G.F., Sant'Ana F.J.F. \& Cunha P.H.J. 2018. Alterações clínicas e histopatológico de bovinos intoxicados experimentalmente por diferentes doses de barbatimão (Stryphnodendron obovatum). Pesq. Vet. Bras. 38 (Supl.):309-310.

Brito M.F., Tokarnia C.H. \& Peixoto P.V. 2001b. Intoxicação experimental pelas favas de Stryphnodendron obovatum (Leg. Mimosoideae) em bovinos. 2. Achados anátomo e histopatológicos. Pesq. Vet. Bras. 21(2):61-71. <http://dx.doi.org/10.1590/S0100-736X2001000200004>

Brito M.F., Tokarnia C.H., Peixoto P.V., Silva H.K. \& Nogueira M. 2001a. Intoxicação experimental pelas favas de Stryphnodendron obovatum (Leg. Mimosoideae) em bovinos. 1. Caracterização do quadro clínico. Pesq. Vet. Bras. 21(1):9-17.<http://dx.doi.org/10.1590/S0100-736X2001000100004>

Camargo W. 1965. Fotossensibilização em bovinos por "barbatimão" (Stryphnodendron obovatum Benth.) fam. Leguminosae. Arqs Inst. Biológico, São Paulo, 31(1):7-11.
Driemeier D., Barros S.S., Peixoto P.V., Tokarnia C.H., Döbereiner J. \& Brito M.F. 1998. Estudos histológico, histoquímico e ultraestrutural de fígados e linfonodos de bovinos com presença de macrófagos espumosos ("foam cells"). Pesq. Vet. Bras. 18(1):29-34. <http://dx.doi.org/10.1590/S0100-736X1998000100005>

Ferreira E.V., Boabaid F.M., Arruda L.P., Lemos R.A.A., Souza M.A., Nakazato L. \& Colodel E.M. 2009. Intoxicação por Stryphnodendron fissuratum (Mimosoideae) em bovinos. Pesq. Vet. Bras. 29(11):951-957. <http://dx.doi.org/10.1590/S0100-736X2009001100015>

INMET 2018. Instituto Nacional de Meteorologia, Ministério da Agricultura, Pecuária e Abastecimento. Available at <http://www.inmet.gov.br> Accessed on Aug. 9, 2019.

Lazaro N.D., Bacha F.B., Pupin R.C., Paula J.P.L., Leal P.V., Pott A., Gomes D.C. \& Lemos R.A.A. 2018. Photosensitization in cattle caused by spontaneous and experimentally ingestion of Stryphnodendron fissuratum. Acta Scient. Vet. 46:1542. <http://dx.doi.org/10.22456/1679-9216.81829>

Lemos R.A.A. \& Lima S.C. 2017. Plantas tóxicas de interesse pecuário na região Centro-Oeste do Brasil. Revta Acad. Ciênc. Anim. 15(Supl.2):S33-S43. <http://dx.doi.org/10.7213/academica.15.S02.2017.A05>

Oliveira D.R. 2010. Contribuição ao estudo da bioprospecção farmacológica de plantas medicinais do nordeste brasileiro: barbatimão (Stryphnodendron rotundifolium Mart.). Master's Thesis, Universidade Regional do Cariri, Crato. 161p.

Scalon V.R. 2007. Revisão taxonômica do gênero Stryphnodendron Mart. (Leguminosae-Mimosoideae). Doctoral Dissertation, Universidade de São Paulo, São Paulo. 273p.

Souza R.I.C., Riet-Correa F., Barbosa-Ferreira M., Brum K.B., Fernandes C.E. \& Lemos R.A.A. 2010. Intoxicação por Brachiaria spp. em bovinos no Mato Grosso do Sul. Pesq. Vet. Bras. 30(12):1036-1042. <http://dx.doi.org/10.1590/S0100-736X2010001200006>

Tokarnia C.H., Brito M.F., Driemeier D., Costa J.B.D. \& Camargo A.J.R. 1998. Aborto em vacas na intoxicação experimental por Stryphnodendron obovatum (Leg. Mimosoideae). Pesq. Vet. Bras. 18(1):35-38. <http://dx.doi.org/10.1590/S0100-736X1998000100006>

Tokarnia C.H., Brito, M.F., Barbosa J.D., Peixoto P.V. \& Döbereiner J. 2012. Plantas Tóxicas do Brasil. 2 $2^{\mathrm{a}}$ ed. Editora Helianthus, Rio de Janeiro.

Werner P.R. 2011. Patologia Geral Veterinária Aplicada. Editora Roca, São Paulo. 384p. 